\title{
Nieuw onderzoek naar pijnbestrijding bij kinderen met OMA
}

Rick van Uum

Goede pijnstilling is de hoeksteen van de behandeling van kinderen met een acute middenoorontsteking (OMA). In de praktijk blijken huisartsen pijnstilling echter vaak niet expliciet met de ouders te bespreken. In een nieuw onderzoek wordt bekeken of het optimaliseren van pijnbestrijding een gunstig effect heeft op de klachten van het kind, het aantal vervolgconsulten en het antibioticagebruik.

Oorpijn is vaak het prominente symptoom van OMA en blijkt voor zowel ouders als kinderen van groot belang. De huidige NHG-Standaard adviseert huisartsen dan ook om alle kinderen met een OMA goede pijnstilling te geven. ${ }^{1}$ De indicatie voor antibiotica is beperkt: kinderen met een verhoogd risico op complicaties, dubbelzijdige OMA bij kinderen onder de 2 jaar, kinderen met een OMA en een loopoor. Zowel paracetamol (alle leeftijden) als ibuprofen (1 jaar en ouder) zijn geschikt bij de bestrijding van oorpijn bij kinderen met een OMA. ${ }^{1}$ Beide zijn bewezen effectief en veilig. $^{2-4}$

In de praktijk ligt de focus vaak nog op het bestrijden van de infectie zelf, inclusief de beslissing om deze al dan niet met een antibioticum te behandelen, en is er onvoldoende aandacht voor goede pijnstilling. ${ }^{2,5,6}$ Ouders vinden pijnstilling alleen vaak niet afdoende. Eerdere ervaringen en adviezen van de huisarts spelen hierbij een belangrijke rol. ${ }^{7}$ Optimaliseren van het pijnbeleid lijkt zinvol.

\section{In de praktijk ligt de focus vaak nog op het bestrijden van de infectie zelf}

Sinds januari 2015 voeren wij een pragmatisch, clustergerandomiseerd onderzoek uit waarin we de effectiviteit van een meervoudige educatieve interventie, gericht op het optimaliseren van pijnbestrijding bij kinderen met OMA, vergelijken met de gebruikelijke zorg. De interventie betreft een onderwijsmodule voor de huisarts die bestaat uit een e-learning en praktijkvisite door de arts-onderzoeker, een interactieve informatiefolder over pijnstilling voor ouders en het voor-

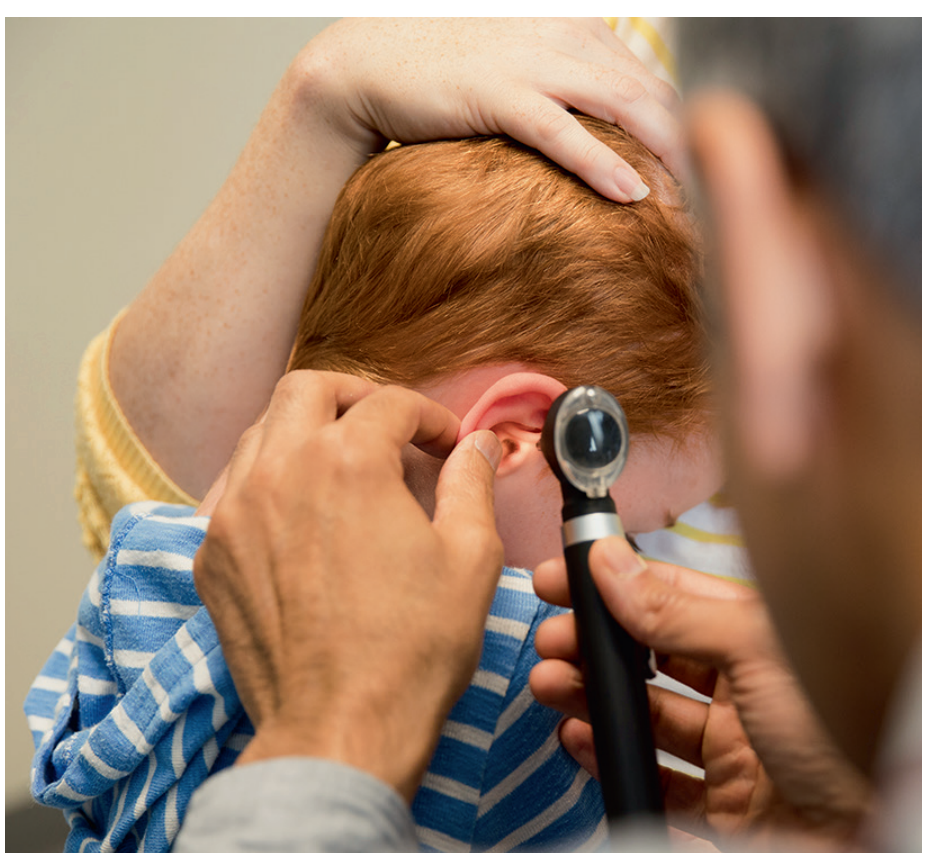

Bij oorpijn vinden ouders pijnstilling alleen vaak niet afdoende. Foto: istock

schrijven van pijnstillers. De uitkomstmaten zijn ernst en duur van pijnklachten, koorts, aantal vervolgconsulten, antibioticagebruik en kosteneffectiviteit. De resultaten worden eind 2018 verwacht. -

\section{LITERATUUR}

1. Damoiseaux RAMJ, Venekamp RP, Eekhof JAH, Bennebroek Gravenhorst FM, Schoch AG, Wittenberg J, et al. NHG-Standaard Otitis media acuta bij kinderen. Huisarts Wet 2014;57:648.

De volledige literatuurlijst staat bij dit artikel op www.henw.org.

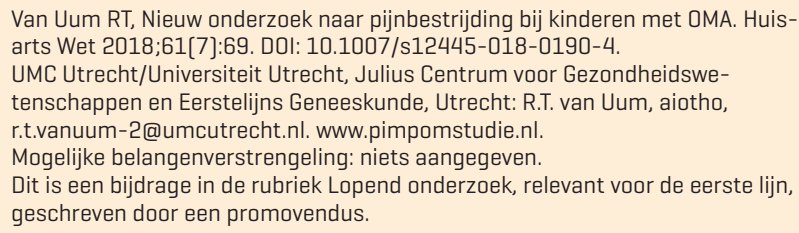

Van Uum RT, Nieuw onderzoek naar pijnbestrijding bij kinderen met OMA. Huisarts Wet 2018;61[7]:69. DOI: 10.1007/s12445-018-0190-4.

UMC Utrecht/Universiteit Utrecht, Julius Centrum voor Gezondheidswetenschappen en Eerstelijns Geneeskunde, Utrecht: R.T. van Uum, aiotho,

r.t.vanuum-2@umcutrecht.nl. www.pimpomstudie.nl.

Mogelijke belangenverstrengeling: niets aangegeven.

Dit is een bijdrage in de rubriek Lopend onderzoek, relevant voor de eerste lijn, geschreven door een promovendus. 